\title{
Stock structure of the goldband snapper Pristipomoides multidens (Pisces: Lutjanidae) from the waters of northern and western Australia by stable isotope ratio analysis of sagittal otolith carbonate
}

\author{
Stephen J. Newman ${ }^{1, *}$, Richard A. Steckis ${ }^{1}$, John S. Edmonds ${ }^{2}$, Julie Lloyd ${ }^{3}$ \\ ${ }^{1}$ Western Australian Marine Research Laboratories, Fisheries Western Australia, PO Box 20, North Beach, 6020, \\ Western Australia, Australia \\ ${ }^{2}$ Department of Chemistry, De Montfort University, The Gateway, Leicester LE1 98H, United Kingdom \\ ${ }^{3}$ Northern Territory Department of Primary Industry and Fisheries, GPO Box 990, Darwin, 0801, Northern Territory, Australia
}

\begin{abstract}
Measurement of stable isotope ratios $\left({ }^{18} \mathrm{O} /{ }^{16} \mathrm{O}\right.$ and $\left.{ }^{13} \mathrm{C} /{ }^{12} \mathrm{C}\right)$ in the sagittal otolith carbonate from assemblages of goldband snapper Pristipomoides multidens from waters off northern and western Australia revealed location-specific signatures and indicated that fish from all sites sampled within Australia (Exmouth, Rankin Bank, Broome, Vulcan Shoals, Timor Sea, Arafura Sea), Indonesia (Kupang) and Papua New Guinea (Pommern Bay) were different. The significant differences in the isotopic signatures of $P$. multidens demonstrated that there is unlikely to be substantial movement of fish among these distinct adult assemblages. The stable isotopic signatures for the fish from the different locations were persistent through time, and therefore it could be concluded that the fish comprise separate stocks for many of the purposes of fisheries management. The ratios of the stable oxygen isotopes in $P$. multidens were significantly related to sea surface temperatures $\left(r^{2}=0.797\right)$. This study has provided further evidence that measurement of the stable isotope ratios in teleost sagittal otolith carbonate can be a valuable tool in the delineation of fishable stocks or fishery management units of adult fish where the range of distribution of the species in question covers waters with different temperature regimes.
\end{abstract}

KEY WORDS: Goldband snapper - Pristipomoides multidens $\cdot$ Stock structure $\cdot$ Stable isotopes $\cdot$ Otoliths

\section{INTRODUCTION}

The goldband snapper Pristipomoides multidens (Day) is widely distributed throughout the tropical Indo-Pacific Ocean region from Samoa in the Central Pacific to the Red Sea in the western Indian Ocean and from southern Japan south to Australia (Allen 1985). Goldband snapper inhabit hard bottom areas and areas of vertical relief and large epibenthos from depths of 60 to at least $200 \mathrm{~m}$ and are concentrated in

•E-mail: snewman@fish.wa.gov.au depths from 80 to $150 \mathrm{~m}$ (Allen 1985, S.J.N. unpubl. data).

In north-western Australia, goldband snapper are a commercially important species from the Exmouth area $\left(23^{\circ} 30^{\prime} \mathrm{S}\right)$ northwards to the Gulf of Carpentaria (Kailola et al. 1993, S.J.N. unpubl. data). Fisheries for goldband snapper are presently managed across north-western Australia by 2 state-based fishery management agencies which have separate management arrangements, with regional segregation of the bottomfish fisheries. Both states, Western Australia and Northern Territory, support highly valuable mixed gear commercial fisheries for goldband snapper and there- 
fore the identity of individual component stocks is important.

Current management arrangements make no allowance for migratory fish or overlapping stocks across either state or intra-state fishery boundaries. Furthermore, foreign (lndonesian) fishing grounds lie adjacent to the territorial waters of north-western Australia. Consequently, there is a need to identify stocks within these areas in order to assess the impacts of fishing in each area should competitive fishing practices develop. Therefore, it is important to determine whether post-juvenile populations of goldband snapper remain discrete and independent or whether there is evidence of mixing of adult fish among different locations. In this paper, a fish 'stock' refers specifically to post-juvenile fish populations that remain discrete and non-mixing (i.e. independent) and therefore comprise a management unit capable of independent exploitation.

A range of methods have been developed to deduce stock structure (e.g. Ihssen et al. 1981, Pawson \& Jennings 1996) and include analysis of the elemental and stable isotopic composition of teleost otoliths (e.g. Campana et al. 1994, Edmonds et al. 1991, 1992, 1995, 1999, Kalish et al. 1996, Edmonds \& Fletcher 1997). Measurement of the stable isotope ratios of oxygen and carbon in the sagittal carbonate involves the analysis of the main structural constituent of the otoliths and avoids possible biases associated with determination of trace elements (e.g. sample contamination). As the whole otolith is used in the analysis, its isotopic signature represents the entire ontogenetic history and has the potential to reflect the home range of each individual fish.

Previous studies have examined the relationship between the isotopic composition of teleost otolith carbonate and environmental variables. The ${ }^{18} \mathrm{O} /{ }^{16} \mathrm{O}$ ratio in sagittal carbonate is deposited close to oxygen isotopic equilibrium with the surrounding water (Kalish 1991a,b, lacumin et al. 1992, Thorrold et al. 1997). Edmonds \& Fletcher (1997) showed that differences in sea surface temperature provided the basis for different oxygen isotope signatures in the otolith carbonate of the pilchard Sardinops sagax from southwestern Australia and hence demonstrated separation of stocks of adult fish. Variation in the water temperatures to which groups of fish are exposed (as measured by sea surface temperatures) is therefore likely to provide the basis for any differences in oxygen isotopic signatures.

Stable carbon isotope ratios $\left({ }^{13} \mathrm{C} /{ }^{12} \mathrm{C}\right)$ in sagittal otolith carbonate are not deposited in equilibrium with the surrounding water (Mulcahy et al. 1979, Kalish 1991b). Thorrold et al. (1997) demonstrated that metabolic effects apparently generate large isotopic disequilibria in $\delta^{13} \mathrm{C}$ values: Recent studies suggest that variation in $\delta^{13} \mathrm{C}$ may result from changes in metabolic rate as fish mature, as well as changes driven by the environment and/or long-term changes in the behaviour of the fish such as dietary shifts which may be associated with changes in habitat or nutrient sources as fish age (Schwarcz et al. 1998). However, there is still uncertainty in defining all the factors which govern the stable carbon isotope composition of sagittal carbonate.

The delineation of stock structure from analysis of the stable isotopic composition of teleost otoliths assumes that geographically distinct stocks possess a characteristic isotopic signature that reflects the isotopic composition of the water body in which the fish is resident. However, as discussed in earlier works (Edmonds \& Fletcher 1997, Edmonds et al. 1999), knowledge of the causai mechanisms responsible for the stable isotopic composition of teleost otolith carbonate is not necessary for any measured differences to delineate stock structure.

Given the philopatric nature of demersal reef fish, the objective of this study was to determine if a multistock complex of goldband snapper was present across northern and western Australia. If so, then a measurable difference in the oxygen isotope ratios in otoliths from different locations would be expected, because of the variation in sea surface temperatures across northwestern Australia. This study was also designed to determine whether any spatial differences in isotopic signatures of the sagittal carbonate were persistent through time. If spatial differences were found to be consistent through time, it would suggest the populations comprise separate management units capable of independent exploitation for fishery management purposes.

\section{MATERIALS AND METHODS}

Sampling design. Otoliths were collected from 6 locations in north-western Australia (Fig. 1): 4 in Western Australia (Exmouth, Rankin Bank, Broome, Vulcan Shoals); and 2 in the Northern Territory (Timor Sea, Arafura Sea). Additional samples were also taken opportunistically from Kupang, Indonesia, and Pommern Bay in northern Papua New Guinea (Fig. 1). Samples were collected on 2 separate occasions a minimum of 6 mo apart from each region. Otoliths were collected from approximately 40 fish ( 20 females and 20 males) from each sample site on each occasion (Table 1).

Otolith removal and preparation. Sagittae were removed by opening the otic bulla from under the operculum. They were washed in freshwater, allowed to dry and stored in envelopes prior to processing. One 


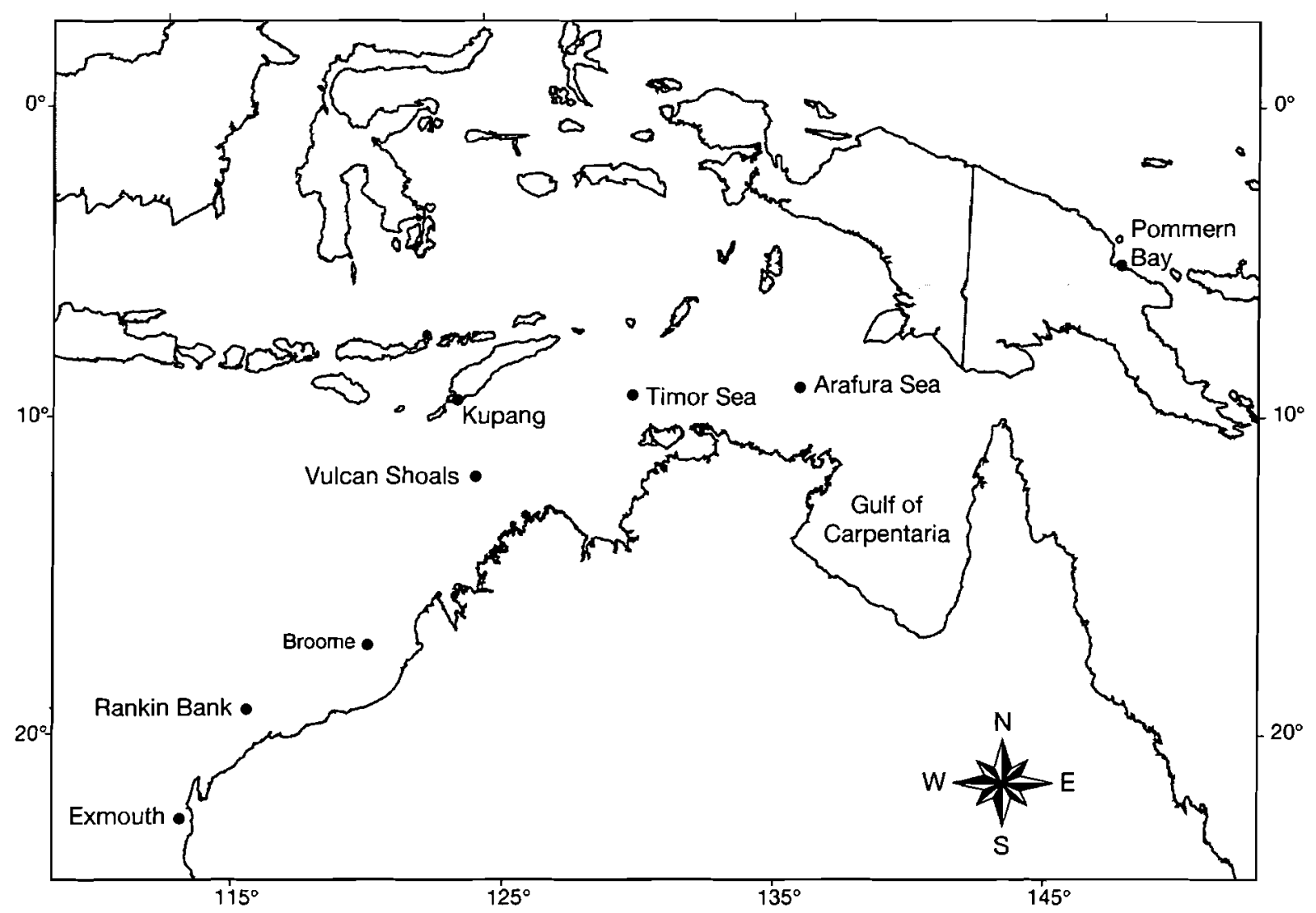

Fig. 1. Sampling locations of the goldband snapper Pristipomoides multidens from north-western Australia, Indonesia and Papua New Guinea

sagitta from each fish was selected at random and cleaned by scrubbing with a nylon brush under high purity (Milli-Q) water, air dried $\left(50^{\circ} \mathrm{C}\right)$ and powdered in an agate mortar and pestle. Powdered sagittae were deproteinated by treatment with hydrogen peroxide and analysed for ${ }^{18} \mathrm{O} /{ }^{16} \mathrm{O}$ and ${ }^{13} \mathrm{C} /{ }^{12} \mathrm{C}$ ratios by standard mass spectrometric techniques (CSIRO Division of Water Resources, Perth) after the carbonate was decomposed to $\mathrm{CO}_{2}$ with $100 \%$ phosphoric acid. Values are reported in standard $\delta$ notation relative to the PDB-1 standard (Epstein et al. 1953).

Statistical analysis. Analysis of covariance (ANCOVA) of the stable isotope values of $\delta^{18} \mathrm{O}$ and $\delta^{13} \mathrm{C}$ were undertaken using otolith weight as a covariate. The 2 factors in the analysis were location and sampling date. The 2 sampling occasions were compared regardless of when they were sampled at each different locality. Thus, location and sampling date were treated as fixed and orthogonal factors in the analysis. Otolith weight is considered to be a proxy for age and therefore was used as a covariate in analyses to adjust treatment means and control error variance across the age range of fish sampled. Type III sums of squares were used to test the hypothesis of differences in pop- ulation means. A posteriori multiple comparison of means $(\alpha=0.05$ ) was conducted using Tukey's honestly significant difference (HSD) method (Day \& Quinn 1989). Initial analyses were carried out on all the data collected with the exception of those from Papua New Guinea, due to the small sample size from that location. In order to remove any confounding effects likely to be associated with a bias of young or old fish sampled at a particular location, to improve homogeneity and normality and to make treatment effects additive, a subsequent analysis was undertaken on data from each location with a similar otolith weight range and presumably age distribution. The otolith weight range selected was from 350 to $650 \mathrm{mg}$. Analyses were carried out in the same manner as described above.

An overall mean $\delta^{18} \mathrm{O}$ value was calculated for each location and plotted against the mean annual sea surface temperature for the 10 yr period from 1989 to 1998 for each location. The annual sea surface temperature (SST) for the years 1989 to 1998 was the average of the 12 monthly means in each of the 10 years and was obtained by the method described by Reynolds \& Smith (1994). 


\section{RESULTS}

Locations sampled, sample numbers, collection dates and results of the $\delta^{18} \mathrm{O}$ and $\delta^{13} \mathrm{C}$ analyses of the sagittal carbonate are summarised in Table 1. All $\delta^{18} \mathrm{O}$ values were plotted against $\delta^{13} \mathrm{C}$ values and revealed grouping of values among locations (Fig. 2). Plots of the relationship between $\delta^{18} \mathrm{O}$ and $\delta^{13} \mathrm{C}$ values against otolith weight (Figs. $3 \& 4$ ) also showed location groupings.

ANCOVA of the $\delta^{18} \mathrm{O}$ values from all the fish samples (except PNG) showed that the location effect was significant (Table 2, Fig. 5). Tukey's (HSD) results indicate that Exmouth values were significantly higher than all other locations sampled; Rankin Bank values in turn were significantly higher than Broome and Kupang values, which were not significantly different from each other; Broome and Kupang values were significantly higher than Vulcan Shoals values, which in turn were significantly higher than the Timor Sea values; the Timor Sea values were significantly higher than the Arafura Sea values. These results are summarised as $\mathrm{EX}>\mathrm{RB}>(\mathrm{BR}=\mathrm{KU})>\mathrm{VS}>\mathrm{TS}>\mathrm{AS}$ (the location codes are defined in Table 1 under each location, > indicates significantly greater differences indicates no significant differences). Location differences alone account for a very high proportion of the variability in the $\delta^{18} \mathrm{O}$ values, accounting for $66 \%$ of the sum of squares. Otolith weight and the location $x$

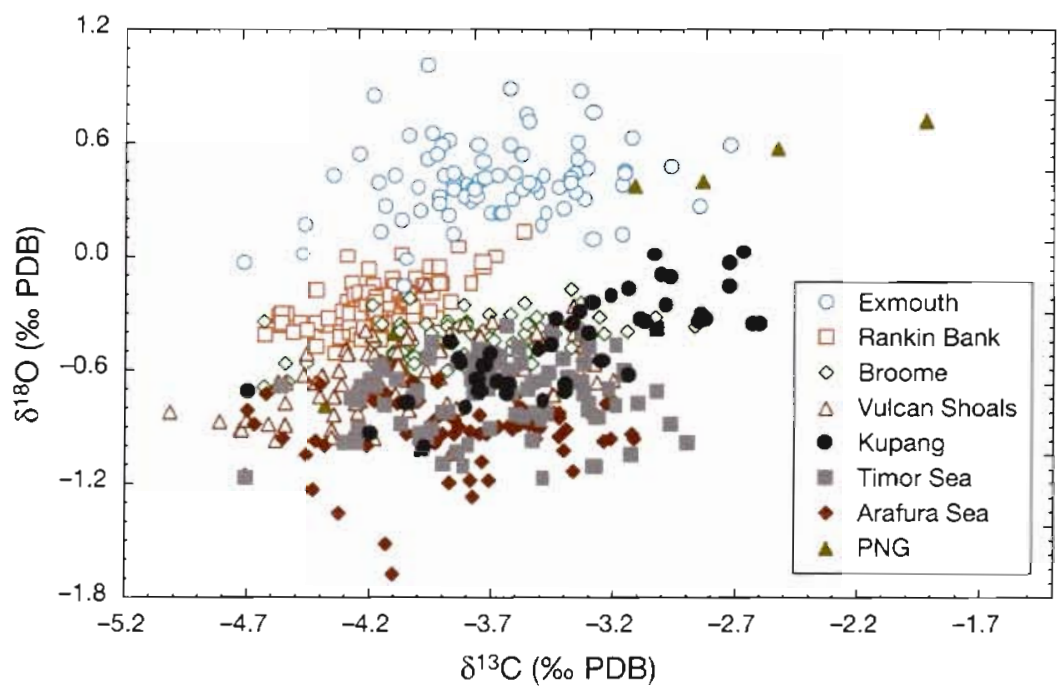

Fig. 2. $\delta^{18} \mathrm{O}$ values versus $\delta^{13} \mathrm{C}$ values of goldband snapper sagittal carbonate for each location for all data

date interaction effects were also significant, but explained only $4 \%$ of the sum of squares (Table 2 ). The location $\times$ date interaction showed a consistent effect across locations except for the Kupang sample. The Kupang samples were obtained from fish markets in Kupang and the actual location of capture is likely to have varied along the coast of Timor, resulting in the significant interaction effect.

ANCOVA of the $\delta^{18} \mathrm{O}$ values from all fish in the selected otolith weight range showed that the location effect was highly significant (Table 3, Fig. 6). Tukey's (HSD) results indicated the following: $\mathrm{EX}>(\mathrm{RB}=\mathrm{KU})$ $>$ BR $>$ VS $>$ TS $>$ AS. This time location differences

Table 1. Summary of all sampling data and results from stable isotope analyses of the sagittal carbonate of Pristipomoides multidens. Mean values (range in parentheses) are given for length, otolith weight and isotope values. SST = mean annual sea surface temperature (average of the 12 monthly means from 1989 to 1998 i Reynolds \& Smith 1994)

\begin{tabular}{|c|c|c|c|c|c|c|c|c|}
\hline $\begin{array}{l}\text { Location } \\
\text { (code) }\end{array}$ & Position & $\begin{array}{l}\text { Date of } \\
\text { sampling }\end{array}$ & $\mathrm{N}$ & $\begin{array}{l}\text { Length } \\
\text { (FL, mm) }\end{array}$ & $\begin{array}{l}\text { Otolith weight } \\
\text { (mg) }\end{array}$ & $\begin{array}{l}\delta^{18} \mathrm{O} \\
(\% \circ \mathrm{PDB})\end{array}$ & $\begin{array}{l}\delta^{13} \mathrm{C} \\
(\% \circ \mathrm{PDB})\end{array}$ & $\begin{array}{l}\text { SST } \\
\left.{ }^{\circ} \mathrm{C}\right)\end{array}$ \\
\hline $\begin{array}{l}\text { Exmouth } \\
(\mathrm{EX})\end{array}$ & $23^{\circ} 30^{\prime} \mathrm{S}, 113^{\circ} 15^{\prime} \mathrm{E}$ & $\begin{array}{l}\text { Jul } 1996 \\
\text { Mar } 1997\end{array}$ & $\begin{array}{l}40 \\
40\end{array}$ & $\begin{array}{l}656(515-742) \\
676(446-845)\end{array}$ & $\begin{array}{l}649(313-931) \\
720(228-1508)\end{array}$ & $\begin{array}{l}0.34(-0.16 \text { to } 0.60) \\
0.48(-0.04 \text { to } 1.02)\end{array}$ & $\begin{array}{l}-3.71(-4.16 \text { to }-3.16) \\
-3.70(-4.72 \text { to }-2.72)\end{array}$ & 24.15 \\
\hline $\begin{array}{l}\text { Rankin Bank } \\
\text { (RB) }\end{array}$ & $19^{\circ} 45^{\prime} \mathrm{S}, 116^{\circ} 00^{\prime} \mathrm{E}$ & $\begin{array}{l}\text { Jul } 1996 \\
\text { Jul } 1997\end{array}$ & $\begin{array}{l}40 \\
40\end{array}$ & $\begin{array}{l}470(385-523) \\
493(411-586)\end{array}$ & $\begin{array}{l}315(198-439) \\
346(239-472)\end{array}$ & $\begin{array}{l}-0.33(-0.71 \text { to }-0.06) \\
-0.19(-0.49 \text { to } 0.14)\end{array}$ & $\begin{array}{l}-4.26(-4.63 \text { to }-3.74) \\
-4.07(-4.57 \text { to }-3.58)\end{array}$ & 26.37 \\
\hline $\begin{array}{l}\text { Broome } \\
\text { (BR) }\end{array}$ & $17^{\circ} 55^{\prime} \mathrm{S}, 120^{\circ} 26^{\prime} \mathrm{E}$ & $\begin{array}{l}\text { Jun } 1996 \\
\text { Mar } 1998\end{array}$ & $\begin{array}{l}40 \\
40\end{array}$ & $\begin{array}{l}522(310-629) \\
492(358-564)\end{array}$ & $\begin{array}{l}349(109-494) \\
545(228-973)\end{array}$ & $\begin{array}{l}-0.43(-0.69 \text { to }-0.17) \\
-0.46(-0.76 \text { to }-0.22)\end{array}$ & $\begin{array}{l}-3.91(-4.63 \text { to }-3.26) \\
-3.70(-4.63 \text { to }-2.87)\end{array}$ & 27.42 \\
\hline $\begin{array}{l}\text { Vulcan Shoals } \\
\text { (VS) }\end{array}$ & $12^{\circ} 45^{\prime} \mathrm{S}, 124^{\circ} 26^{\prime} \mathrm{E}$ & $\begin{array}{l}\text { Jun } 1996 \\
\text { Mar } 1998\end{array}$ & $\begin{array}{l}40 \\
40\end{array}$ & $\begin{array}{l}509(383-615) \\
514(342-613)\end{array}$ & $\begin{array}{l}300(164-408) \\
538(203-942)\end{array}$ & $\begin{array}{l}-0.61(-0.97 \text { to }-0.14) \\
-0.69(-1.03 \text { to }-0.26)\end{array}$ & $\begin{array}{l}-4.24(-5.02 \text { to }-3.52) \\
-3.85(-4.82 \text { to }-3.20)\end{array}$ & 28.44 \\
\hline $\begin{array}{l}\text { Timor Sea } \\
\text { (TS) }\end{array}$ & $10^{\circ} 15^{\prime} \mathrm{S}, 129^{\circ} 48^{\prime} \mathrm{E}$ & $\begin{array}{l}\text { Jun } 1996 \\
\text { Jan } 1997\end{array}$ & $\begin{array}{l}40 \\
40\end{array}$ & $\begin{array}{l}514(357-603) \\
437(307-607)\end{array}$ & $\begin{array}{l}494(237-840) \\
336(171-817)\end{array}$ & $\begin{array}{l}-0.78(-1.17 \text { to }-0.40) \\
-0.71(-1.17 \text { to }-0.37)\end{array}$ & $\begin{array}{l}-3.52(-4.26 \text { to }-2.90) \\
-3.85(-4.71 \text { to }-3.02)\end{array}$ & 28.42 \\
\hline $\begin{array}{l}\text { Arafura Sea } \\
\text { (AS) }\end{array}$ & $9^{\circ} 56^{\prime} S, 135^{\circ} 30^{\prime} E$ & $\begin{array}{l}\text { Jul } 1996 \\
\text { May } 1997\end{array}$ & $\begin{array}{l}45 \\
22\end{array}$ & $\begin{array}{l}481(280-567) \\
484(276-596)\end{array}$ & $\begin{array}{l}489(143-945) \\
482(138-820)\end{array}$ & $\begin{array}{l}-0.87(-1.23 \text { to }-0.65) \\
-1.06(-1.68 \text { to }-0.76)\end{array}$ & $\begin{array}{l}-3.90(-4.71 \text { to }-3.13) \\
-3.66(-4.33 \text { to }-3.12)\end{array}$ & 27.72 \\
\hline $\begin{array}{l}\text { Kupang } \\
(\mathrm{KU})\end{array}$ & $10^{\circ} 20^{\prime} \mathrm{S}, 123^{\circ} 52^{\prime} \mathrm{E}$ & $\begin{array}{l}\text { Apr } 1998 \\
\text { Feb } 1999\end{array}$ & $\begin{array}{l}17 \\
27\end{array}$ & $\begin{array}{l}355\{210-620\} \\
505(310-660\}\end{array}$ & $\begin{array}{l}185(64-593) \\
373(160-680)\end{array}$ & $\begin{array}{l}-0.65(-1.01 \text { to }-0.33) \\
-0.35(-0.68 \text { to } 0.03)\end{array}$ & $\begin{array}{l}-3.59(-4.70 \text { to }-2.60) \\
-3.26(-3.88 \text { to }-2.67)\end{array}$ & 28.39 \\
\hline $\begin{array}{l}\text { Pommern Bay } \\
\text { (PNG) }\end{array}$ & $5^{\circ} 32^{\prime} \mathrm{S}, 146^{\circ} 07^{\prime} \mathrm{E}$ & May 1998 & 9 & $571(335-810)$ & $444(128-1088)$ & $-0.02(-0.79$ to 0.72$)$ & $-3.45(-4.38$ to -1.92$)$ & 28.84 \\
\hline
\end{tabular}




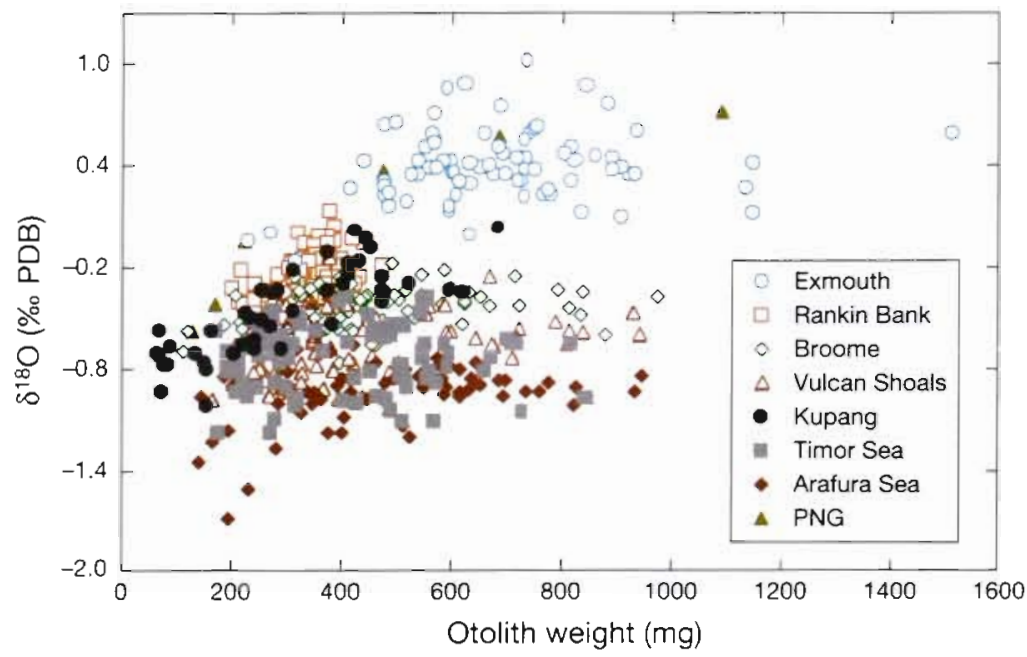

Fig. $3 . \delta^{18} \mathrm{O}$ values of goldband snapper sagittal carbonate versus otolith weight for each location for all data

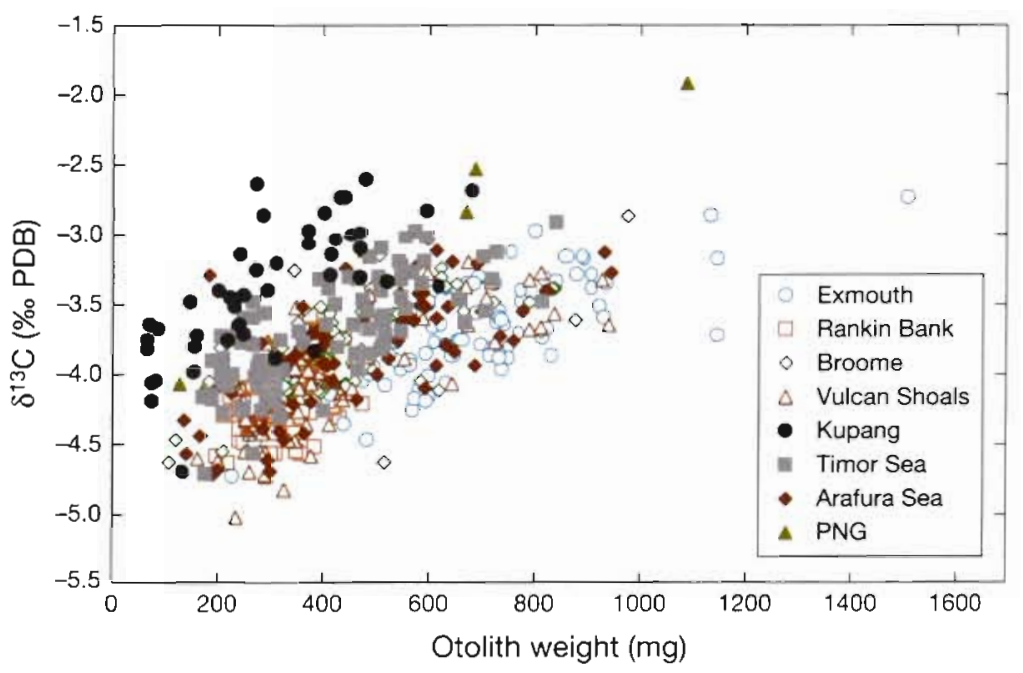

Fig. 4. $\delta^{13} \mathrm{C}$ values of goldband snapper sagittal carbonate versus otolith weight for each location for all data

accounted for $79 \%$ of the sum of squares. Otolith weight and the location $x$ date interaction were significant also, but explained only $3 \%$ of the sum of squares (Table 3). The results of the ANCOVA from the analysis of fish in the selected otolith weight range were a reflection of the ANCOVA results from all the fish sampled. Variation was evident only in fish sampled from Kupang. Separation of locations along the north-west Australian coastline were unchanged (Figs. $5 \& 6$ ). The date of sampling in each analysis was not significant and accounted for less than $0.01 \%$ of the sum of squares in each case, thereby providing no evidence of any temporal variation in $\delta^{18} \mathrm{O}$ values.
ANCOVA of the $\delta^{13} \mathrm{C}$ values from all samples (except PNG) showed that the location effect was significant (Table 4, Fig. 5). Tukey's (HSD) results indicated the following: $\mathrm{KU}>(\mathrm{EX}=\mathrm{BR}=\mathrm{TS}=\mathrm{AS})>$ $(\mathrm{RB}=\mathrm{VS})$. Location differences accounted for a high proportion of the variability in $\delta^{13} \mathrm{C}$ values, explaining $29 \%$ of the sum of squares. Otolith weight and the location $x$ date interaction were also significant, explaining $31 \%$ of the sum of squares (Table 4).

ANCOVA of the $\delta^{13} \mathrm{C}$ values from all fish in the selected otolith weight range showed that the location effect was significant (Table 5, Fig. 6). Tukey's (HSD) results indicated the following: $\mathrm{KU}>\mathrm{TS}>$ $(B R=A S)>(R B=V S=E X)$. Location dif ferences account for $31 \%$ of the sum of squares. Otolith weight and the location $x$ date interaction were also significant, but explained only $12 \%$ of the sum of squares (Table 5). The latter analysis demonstrated better differentiation amongst localities. The most significant result was that fish sampled from Kupang were different to all other locations in each analysis (Figs. 5 \& 6). In each analysis, the date of sampling was not significant, and accounted for less than $0.01 \%$ of the sum of squares in each case, thereby providing no evidence of any temporal variation in $\delta^{13} \mathrm{C}$ values.

While only a small number of samples were obtained from PNG, they were much more variable in $\delta^{13} \mathrm{C}$ and $\delta^{18} \mathrm{O}$ values than for the other locations (Table 1). Such variation in stable isotope values alone indicates that fish sampled from PNG are likely to differ from the other locations.

Mean $\delta^{18} \mathrm{O}$ values for each location were plotted against the mean of the annual sea surface temperatures from 1989 to 1998 for each location (Fig. 7). The linear relationship had an $\mathrm{r}^{2}=0.797$ (excluding the small sample obtained from PNG).

Table 2. ANCOVA of the $\delta^{18} \mathrm{O}$ values of the sagittal carbonate of Pristipomoides multidens (all raw data, excluding PNG)

\begin{tabular}{|lrrrrr|}
\hline Source & $\mathrm{df}$ & \multicolumn{1}{c}{ SS } & MS & $F$ & $\mathrm{p}$ \\
\hline Location & 6 & 69.0042 & 11.5007 & 441.706 & $<0.0001$ \\
Date & 1 & 0.0432 & 0.04325 & 1.6611 & 0.198 \\
Location $\times$ Date & 6 & 2.8292 & 0.47153 & 18.1099 & $<0.0001$ \\
Otolith weight & 1 & 1.6984 & 1.69838 & 65.2295 & $<0.0001$ \\
Residual (Error) & 501 & 13.0445 & 0.02604 & & \\
Total & 515 & 104.9133 & & & \\
\hline
\end{tabular}




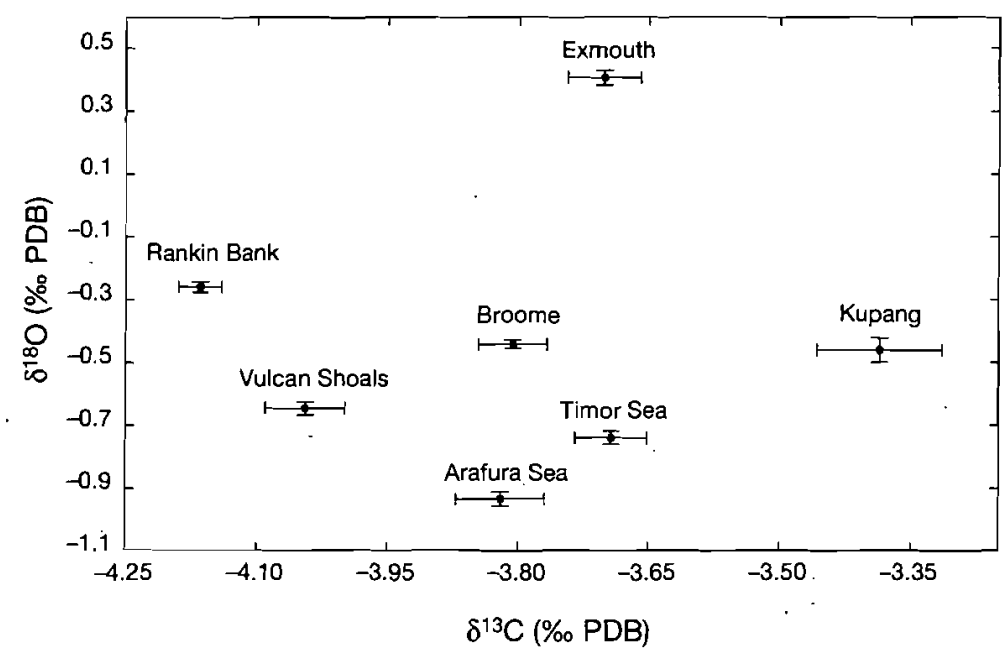

Fig. 5. Mean $\delta^{18} \mathrm{O}$ values $\left( \pm \mathrm{SE}\right.$ ) versus mean $\delta^{13} \mathrm{C}$ values $( \pm \mathrm{SE})$ of goldband snapper sagittal carbonate for each location for all data

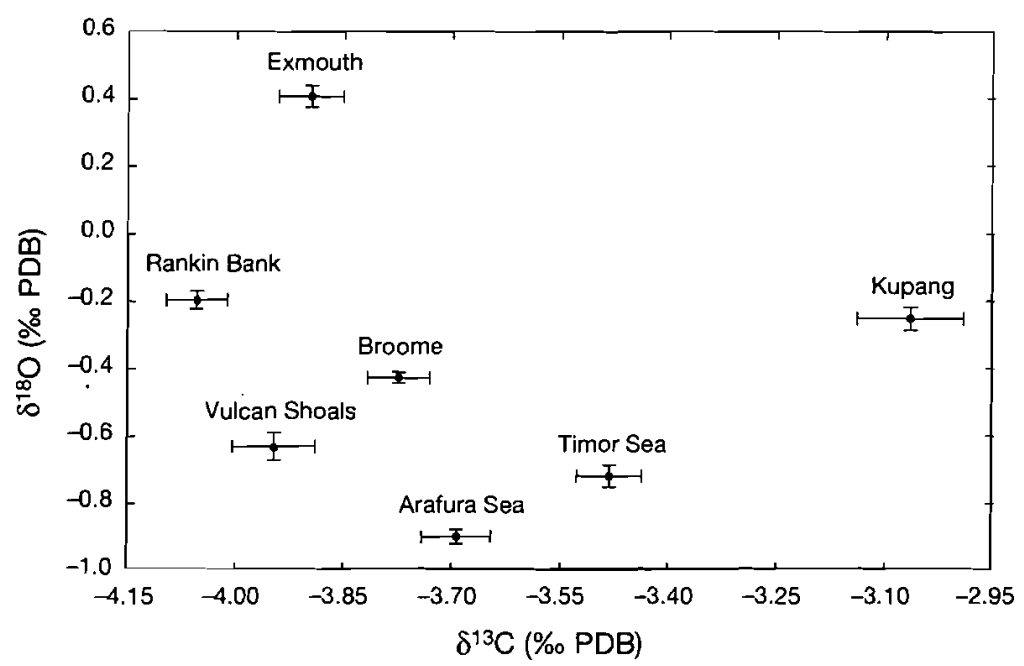

Fig. 6. Mean $\delta^{18} \mathrm{O}$ values $\left( \pm \mathrm{SE}\right.$ ) versus mean $\delta^{13} \mathrm{C}$ values $( \pm \mathrm{SE})$ of goldband snapper sagittal carbonate for each location for selected data (otolith weight range from 350 to $650 \mathrm{mg}$ only)

Table 3. ANCOVA of the $\delta^{18} \mathrm{O}$ values of the sagittal carbonate of Pristipomoides multidens (selected data: otolith weight range from 350 to $650 \mathrm{mg}$, excluding PNG)

\begin{tabular}{|lrrrrc}
\hline Source & df & \multicolumn{1}{c}{ SS } & MS & $F$ & p \\
\hline Location & 6 & 35.9972 & 5.9995 & 267.087 & $<0.0001$ \\
Date & 1 & 0.0059 & 0.0059 & 0.2636 & 0.608 \\
Location $\times$ Date & 6 & 1.4424 & 0.2404 & 10.7018 & $<0.0001$ \\
Otolith weight & 1 & 0.1777 & 0.1777 & 7.9089 & $<0.01$ \\
Residual (Error) & 223 & 5.0092 & 0.0225 & & \\
Total & 237 & 45.7339 & & & \\
\hline
\end{tabular}

\section{DISCUSSION}

The observed pattern of variation in oxygen isotope ratios supported the hypothesis that differences in oxygen isotope values among locations could be explained by the relative differences in water temperature (which are dependent upon latitude) across northern Australia, with the lowest oxygen isotope values, indicating the highest mean water temperatures, being found in fish from the Vulcan Shoals, Timor Sea and Arafura Sea (see. Fig. 7). Conversely, the highest oxygen isotope values, indicating the lowest mean water temperatures, were found in fish from Exmouth (Fig. 7). Hence, the relationship between sea surface temperature and $\delta^{18} \mathrm{O}$ values was linear (Fig. 7).

The $\delta^{18} \mathrm{O}$ values represent a mean value integrated over the entire ontogenetic life history of each individual fish, which may range in age from 3 to possibly $30 \mathrm{yr}$ (S.J.N. unpubl. data). Oxygen isotope signatures for all locations were significantly different and reflected different environmental conditions, indicating that the adult fish had remained resident in places that offered different temperature regimes. If the adult fish were mixing among locations then isotopic signatures amongst locations would be similar, as was the case for tailor Pomatomus saltatrix in mid-western Australia (Edmonds et al. 1999). Adult goldband snapper populations are spatially distinct and non-mixing and can be considered as independent management units or stocks for the purposes of fisheries management.

The $\delta^{18} \mathrm{O}$ and $\delta^{13} \mathrm{C}$ values obtained from the sagittal carbonate of goldband snapper collected from PNG were more variable than those collected from other locations. This variability alone is indicative of the separation of the adult fish in this area and elsewhere, suggesting they also were a separate stock. Values for $\delta^{18} \mathrm{O}$ otolith carbonate from the small number of fish sampled from PNG were higher than expected from considerations of water temperature alone (Fig. 7). This suggested that the fish (captured from 100 to $200 \mathrm{~m}$ water depth) were resident in colder waters below the thermocline separating such waters from the lens of warm surface 
Table 4. ANCOVA of the $\delta^{13} \mathrm{C}$ values of the sagittal carbonate of Pristipomoides multidens (all raw data, excluding PNG)

\begin{tabular}{|lrccrc|}
\hline Source & df & SS & MS & $F$ & $p$ \\
\hline Location & 6 & 27.4837 & 4.58062 & 66.4341 & $<0.0001$ \\
Date & 1 & 0.04259 & 0.04259 & 0.6177 & 0.432 \\
Location x Date & 6 & 1.81527 & 0.30255 & 4.3879 & $<0.0001$ \\
Otolith weight & 1 & 28.1482 & 28.1482 & 408.2425 & $<0.01$ \\
Residual (Error) & 501 & 34.5439 & 0.06895 & & \\
Total & 515 & 95.8702 & & & \\
\hline
\end{tabular}

Table 5. ANCOVA of the $\delta^{13} \mathrm{C}$ values of the sagittal carbonate of Pristipomoides multidens (selected data: otolith weight range from 350 to $650 \mathrm{mg}$, excluding PNG)

\begin{tabular}{|lrcccc|}
\hline Source & df & SS & MS & $F$ & $\mathrm{p}$ \\
\hline Location & 6 & 10.8490 & 1.8082 & 27.3585 & $<0.0001$ \\
Date & 1 & 0.00097 & 0.00097 & 0.01466 & 0.904 \\
Location × Date & 6 & 1.13859 & 0.18977 & 2.87124 & 0.010 \\
Otolith weight & 1 & 2.83895 & 2.83895 & 42.9548 & $<0.0001$ \\
Residual (Error) & 223 & 14.7384 & 0.06609 & & \\
Total & 237 & 34.6010 & & & \\
\hline
\end{tabular}

Variation in $\delta^{13} \mathrm{C}$ values of all the goldband snapper sampled were more attributable to otolith weight than location of capture. However, when the otolith weight range was restricted, variation in $\delta^{13} \mathrm{C}$ values of the goldband snapper were more attributable to location of capture than to otolith weight. This result is consistent with the hypothesis of Kalish (1991b) that $\delta^{13} \mathrm{C}$ values are dependent to a large degree on metabolic rate, with higher rates resulting in greater depletion of otolith $\delta^{13} \mathrm{C}$. Hence, when the age range was restricted (otolith weight is considered a proxy for fish age). variation in $\delta^{13} \mathrm{C}$ values were more attributable to location of capture. The $\delta^{13} \mathrm{C}$ data clearly demonstrated that fish from Kupang, Indonesia, were distinctly different from the other locations. The separation between this sample and those from the continental shelf of Australia is not surprising given that they are separated by the Timor Trench, which is approximately $2000 \mathrm{~m}$ deep. This suggests that the Timor Trench is an effective barrier to adult movement between the continental shelf waters of Australia and the islands of Indonesia.

This study has provided further evidence that measurement of stable isotope ratios in teleost sagittal carbonate is a valuable tool in discerning fishery management units of adult fish where the range of distribution of the species includes waters with different temperature regimes. water influenced by the isotopically light rainfall typical of equatorial regions (M. Gagan pers. comm.). Furthermore, temperature profiles with depth for different latitudes indicate that low latitudes possess the largest variation in temperature with water depth (Millero \& Sohn 1989). This, provides a potential explanation for the variation in isotopic composition of otoliths from PNG fish.

\section{Fishery management implications}

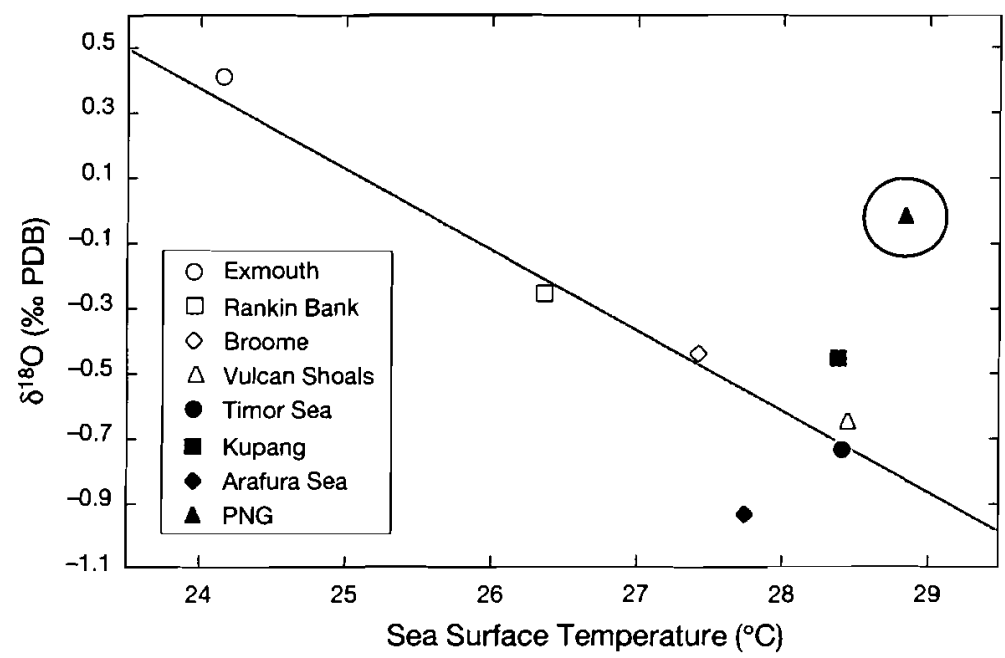

Fig. 7. Mean $\delta^{18} \mathrm{O}$ values of goldband snapper sagittal carbonate for each location for all data versus mean sea surface temperatures from 1989 to 1998 (derived from the average monthly sea surface temperatures from 1989 and 1998; see Reynolds \& Smith 1994) for each location. The PNG data point is circled
Oxygen and carbon stable isotope values in this study have shown distinct location-specific isotope signatures which strongly support the hypothesis of a multistock complex of goldband snapper across north-western Australia. This multi-stock complex persists through time and can be separated into a number of distinct stocks or management units. These stocks are (1) Exmouth, (2) Rankin Bank, (3) Broome, (4) Vulcan Shoals, (5) Timor Sea, (6) Arafura Sea, (7) Kupang (Indonesia) and (8) Pommern Bay (Papua New Guinea). Further subdivision may have been revealed with a more closely spaced sampling regime. While stocks are effectively isolated from each other, recruitment to each stock across north-western Australia may be derived from a common gene pool (if there 
is an absence of significant genetic variation among stocks). Westward and southward directed movement of eggs and larvae is highly probable under the influence of the Indonesian Throughflow and the Leeuwin Current and therefore stocks may be well mixed in the genetic sense. The gene flow between goldband snapper populations across northern Australia is currently being investigated ( $\mathrm{J}$. Ovenden et al. pers. comm.).

A high probability of connectivity or intermixing during the egg and larval stages across a multi-stock complex of separate and distinct adult stocks implies that the size of the total adult spawning stock (i.e. the combined sum of each of the separate adult stocks) could impact recruitment. Thus, fishing on any one stock could impact fishing on any other stock, through subsequent recruitment (resulting from a reduced spawner biomass). However, direct impacts of fishing on one stock should not affect adjacent stocks (or any fishing impact should be negligible).

Recruitment in fish stocks is inherently variable and usually depends on both the total spawner biomass and prevailing oceanographic conditions at the time of spawning. Consequently, one stock may produce relatively high recruitment one year or over a series of years, while another stock suffers from poor recruitment. If fish stocks suffer from localised depletion (removal of spawners and hence older age classes) and local recruitment is poor (no juveniles available in subsequent years), then the recovery of the stock will depend on the rate of supply of external recruits. Under these circumstances, it may be difficult for stocks to recover, and the recovery cycle may be on the order of decades in long lived fishes such as goldband snapper. Given the need for external recruitment in the replenishment of local depletion events and an initial adult stock structure which consists of at least $20+$ age classes (e.g. ages 5 to at least 25), then a serious local depletion event would require a minimum of $20 \mathrm{yr}$ for the stock to recover in terms of both spawner biomass and age structure.

Separation of stocks and the delineation of stock structure allows management units to be defined. The presence of a multi-stock complex of goldband snapper indicates that management can be applied separately to each of the stocks at the regional or location level along the north-western Australian coast. However, a more robust or cautionary approach to fisheries management is recommended whereby each state management agency should aim to maintain an adequate total spawner biomass within each fishable stock and avoid localised depletion events. This cautionary approach to management applies to both state-based management agencies within Australia and also to cross-border management agencies within Indonesia given the adjacent nature of fishing grounds in northern Australian waters.
Acknowledgements. The authors gratefully acknowledge funding from the Fisheries Research and Development Corporation (FRDC) for this project. This work was undertaken as part of FRDC Project No. 98/154. Stable isotope analyses were carried out by the CSIRO Division of Water Resources (Dr J. V. Turner). Logistical support was provided by Fisheries Western Australia. The authors are grateful to the trap, line and trawl fishers of Western Australia and the Northern Territory in particular Andy, Shirley and Matt Cassidy, and Doug Gibson; Bob and Adam Masters, Lou Michielsen, Mal Reid and Bill Passey for the provision of fish samples; and Adrian Flynn (NSR Environmental Consultants Pty. Ltd.) for the provision of fish samples from Papua New Guinea. Josef Nduru and his staff at Dinas Perikanan Propensi NTT graciously assisted with the collection of samples from Kupang. This manuscript benefited from discussions with Dr Trevor Bastow and Dr Henry Cheng (Fisheries Western Australia) and Dr Michael Gagan (Research School of Earth Sciences, The Australian National University). We would also like to thank Charles Bryce, lain Dunk, Ryan Ashworth, Jerry Jenke, Peta Williamson, Muriel Brasseur, Alana Kidd and Jenny Moore for help and assistance throughout this project.

\section{LITERATURE CITED}

Allen GR (1985) FAO species catalogue, Vol 6. Snappers of the world. An annotated and illustrated catalogue of lutjanid species known to date. FAO Fisheries Synopsis No. 125, FAO, Rome

Campana SE, Fowler AJ, Jones CM (1994) Otolith elemental fingerprinting for stock identification of Atlantic cod (Gadus morhua) using laser ablation ICPMS. Can J Fish Aquat Sci 51:1942-1950

Day RW, Quinn GP (1989) Comparisons of treatments after an analysis of variance in ecology. Ecol Monogr 59(4):433-463

Edmonds JS, Fletcher WJ (1997) Stock discrimination of pilchards Sardinops sagax by stable isotope ratio analysis of otolith carbonate. Mar Ecol Prog Ser 152:241-247

Edmonds JS, Caputi N, Morita M (1991) Stock discrimination by trace-element analysis of otoliths of Orange Roughy (Hoplostethus atlanticus), a deep-water marine teleost. Aust J Mar Freshw Res 42:383-389

Edmonds JS, Lenanton RCJ, Caputi N, Morita M (1992) Trace elements in the otoliths of yellow-eye mullet (Aldrichetta forsterl) as an aid to stock identification. Fish Res 13:39-51

Edmonds JS, Caputi N, Moran MJ, Fletcher WJ, Morita M (1995) Population discrimination by variation in concentrations of minor and trace elements in sagittae of two Western Australian teleosts. In: Secor DH, Dean JM, Campana SE (eds) Recent developments in fish otolith research. University of South Carolina Press, Columbia, p 655-670

Edmonds JS, Steckis RA, Moran MJ, Caputi N, Morita M (1999) Stock delineation of pink snapper Pagrus auratus and tailor Pomatomus saltatrix from Western Australia by analysis of stable isotope and strontium/calcium ratios in otolith carbonate. J Fish Biol 55:243-259

Epstein S, Buchsbaum R, Lowenstam HA, Urey HC (1953) Revised carbonate-water isotopic temperature scale. Bull Geol Soc Am 64:1315-1326

lacumin P, Bianucci G, Longinelli A (1992) Oxygen and carbon isotopic composition of fish otoliths. Mar Biol 113: $537-542$

lhssen PE, Booke HE, Casselman JM, McGlade JM, Payne NR, Utter FM (1981) Stock identification: materials and methods. Can J Fish Aquat Sci 38:1838-1855 
Kailola PJ, Williams MJ, Stewart PC, Reichelt RE, McNee A, Grieve C (1993) Australian fisheries resources. Bureau of Resource Sciences, Department of Primary Industries and Energy, and the Fisheries Research and Development Corporation, Canberra

Kalish JM (1991a) Oxygen and carbon stable isotopes in the otoliths of wild and laboratory-reared Australian salmon (Arripis trutta). Mar Biol 110:37-47

Kalish JM (1991b) ${ }^{13} \mathrm{C}$ and ${ }^{18} \mathrm{O}$ disequilibria in fish otoliths: metabolic and kinetic effects. Mar Ecol Prog Ser 75:191-203

Kalish JM, Liningston ME, Schofield KA (1996) Trace elements in the otoliths of New Zealand blue grenadier (Macruronus novaezelandiae) as an aid to stock discrimination. Mar Freshw Res 47:537-542

Millero FJ, Sohn ML (1989) Chemical oceanography, 2nd edn. CRC Press, London

Mulcahy SA, Killingley JS, Phleger CF, Berger WH (1979) Iso-

Editorial responsibility: Kenneth Sherman (Contributing Editor), Narragansett, Rhode Island, USA topic composition of otoliths of a benthopelagic fish, Coryphaenoides acrolepis, Macrouridae: Gadiformes. Oceanol Acta 2:423-427

Pawson MG, Jennings S (1996) A critique of methods for stock identification in marine capture fisheries. Fish Res 25: 203-217

Reynolds RW, Smith TM (1994) Improved global sea surface temperature analyses using optimum interpolation. J Clim $7: 929-948$

Schwarcz HP, Gao Y, Campana S, Browne D, Knyf M, Brand $U$ (1998) Stable carbon isotope variations in otoliths of Atlantic cod (Gadus morhua). Can J Fish Aquat Sci 55: 1798-1806

Thorrold SR, Campana SE, Jones CM, Swart PK (1997) Factors determining $\delta^{13} \mathrm{C}$ and $\delta^{18} \mathrm{O}$ fractionation in aragonitic otoliths of marine fish. Geochim Cosmochim Acta 61: 2909-2919

Submitted: August 15, 1999; Accepted: November 18, 1999 Proofs received from author(s): May 15, 2000 